\title{
Warunki rejestracji i zakres ochrony kompozycji kolorystycznej jako znaku towarowego w świetle przepisów krajowych oraz dyrektywy 2015/2436
}

\section{Wprowadzenie}

Katalog oznaczeń, które mogą pełnić funkcję znaku towarowego jest bardzo Kszeroki. De lege lata przyjmuje się, że wśród oznaczeń o charakterze graficznym mogą to być nie tylko oznaczenia o „zamkniętej kompozycji” (jak można by to określić posiłkując się terminologią zaczerpniętą z historii sztuki), ale również kolor lub też kolory jako takie, czyli barwy bezkonturowe. Głównym celem prezentowanego artykułu jest omówienie podstawowych warunków i zakresu ochrony znaków towarowych stanowiących zestawienie dwóch lub więcej kolorów per se. W odniesieniu bowiem do tego typu oznaczeń pojawiają się wątpliwości, jak należy przedstawiać je w rejestrze znaków towarowych oraz jak daleko rozciąga się prawo wyłączne do takich oznaczeń. Czy uprawniony do znaku stanowiącego zestawienie dwóch lub więcej kolorów uzyskuje monopol na posługiwanie się wybranymi przez siebie barwami w odniesieniu do wymienionych w zgłoszeniu towarów? Czy też mamy tu do czynienia z pewnymi ograniczeniami?

W polskiej ustawie - Prawo własności przemysłowej (dalej p.w.p. $)^{1}$ dla omawianych oznaczeń używa się określenia „kompozycja kolorystyczna”. Zgodnie

\footnotetext{
* Dr Joanna Sitko - Katedra Organizacji Przedsiębiorstwa Wydziału Zarządzania Politechniki Lubelskiej; e-mail: j.sitko@pollub.pl

${ }^{1}$ Ustawa z dnia 30.06.2000 r. (tekst jedn. Dz. U. z 2017 r. poz. 776 ze zm.).
} 
bowiem $\mathrm{z}$ art. 120 ust. 2 p.w.p. znakiem towarowym może być $\mathrm{w}$ szczególności „wyraz, rysunek, ornament, kompozycja kolorystyczna (zaznaczenie własne J.S.), forma przestrzenna, w tym forma towaru lub opakowania, a także melodia lub inny sygnał dźwiękowy”. Jest to określenie bliskie terminowi „układ kolorów”, który został użyty w art. 15 ust. 1 zd. 2 TRIPS 2 .

Natomiast dyrektywa 2015/2436 , która ma zostać inkorporowana do prawa polskiego do dnia 14 stycznia 2019 r. nie zawiera pojęcia kompozycji kolorystycznej. Wydaje się, że odpowiednikiem tego określenia na gruncie wspomnianej dyrektywy jest pojęcie „kolory”. W myśl bowiem art. 3 dyrektywy 2015/2436 znak towarowy może składać się z jakichkolwiek oznaczeń, w szczególności $\mathrm{z}$,wyrazów, łącznie z nazwiskami, lub rysunków, liter, cyfr, kolorów (zaznaczenie własne - J.S.), kształtu towarów lub ich opakowań lub dźwięków (...)”. Powstaje więc pytanie, czy wymienione w cytowanym przepisie słowo „kolory” można utożsamiać z pojęciem „kompozycja kolorystyczna”, o którym mowa w art. 120 ust. 2 p.w.p., czy też należałoby nadać mu odmienne znaczenie. Gramatyczna wykładnia tych pojęć pozwala na dostrzeżenie istotnych różnic pomiędzy nimi. Wydaje się bowiem, że interpretacja językowa przepisu dyrektywy skłania do przyjęcia, że znakiem towarowym mogą być dowolnie wybrane kolory per se bez względu na ich wzajemną konfigurację. Natomiast w pojęciu kompozycji kolorystycznej zawarte jest odniesienie do określonego układu kolorów, które skonfigurowane (skomponowane) są w zadany sposób. Wydaje się jednak, że wskazana różnica pojęciowa nie powinna mieć znaczenia merytorycznego dla analizowanego zagadnienia ochrony zestawienia kolorów jako takich ze względu po pierwsze, na otwarty katalog form przedstawieniowych znaków towarowych zawarty w obu cytowanych przepisach ${ }^{4}$. Po drugie, niezależnie od różnic wynikających $\mathrm{z}$ interpretacji warstwy językowej porównywanych określeń, należy przyjąć, że zarówno na gruncie dyrektywy 2015/2436, jak i ustawy p.w.p. warunki rejestracji i zakres ochrony znaków stanowiących kompozycję kolorów per se powinien być interpretowany analogicznie ze względu na konieczność harmonizacji polskiego prawa z prawem UE w odniesieniu do zagadnień objętych postanowieniami dyrektywy. O tym jakie cechy musi spełniać kompozycja

${ }^{2}$ Załącznik 1 c do Porozumienia w sprawie ustanowienia Światowej Organizacji Handlu - WTO sporządzonego w Marakeszu dnia 15.04.1994 r (Dz.U. z 1996 r., Nr 32, poz. 143).

${ }^{3}$ Dyrektywa Parlamentu Europejskiego i Rady (UE) 2015/2436 z dnia 16.12.2015 r. mająca na celu zbliżenie ustawodawstw państw członkowskich odnoszących się do znaków towarowych (Dz. Urz. UE L336/01).

${ }^{4}$ Zob. też uwagi na temat konieczności dokonania zmian w polskiej ustawie w zakresie postanowień dotyczących możliwości rejestracji pojedynczego koloru M. Kępiński, Projekt nowej dyrektywy dotyczącej znaków towarowych i jej możliwe konsekwencje dla ustawodawcy polskiego, PPWI UJ 2014/126, s. 47. Autor twierdzi, że: „Nasze prawo dopuszcza obecnie kompozycję kolorystyczną jako znak towarowy i będzie wymagać uzupełnienia co do dopuszczalności rejestracji pojedynczego koloru.” 
kolorów jako takich, aby mogła uzyskać ochronę w charakterze znaku towarowego, szczegółowo będzie mowa w kolejnym punkcie artykułu.

Warto również na wstępie odnieść się do nazewnictwa używanego w rejestrze znaków towarowych Urzędu Patentowego RP (dalej UPRP) oraz Urzędu Unii Europejskiej ds. Własności Intelektualnej (dalej EUIPO) dla określenia tej kategorii znaków, do których zalicza się kompozycję dwóch lub więcej kolorów jako takich. Jest to bardzo istotne zagadnienie, gdyż np. znak przedstawiający dwa jednakowej wielkości prostokąty różnego koloru, może stanowić zarówno znak graficzny w postaci dwóch przylegających do siebie różnokolorowych figur geometrycznych (o zadanych kształtach), jak też może być ilustracją pozbawionej konturów kompozycji kolorystycznej dwóch barw. W pierwszym przypadku w rejestrze znaków towarowych prowadzonym przez EUIPO stosuje się pojęcie „znak obrazowy” (,figurative mark”), a w drugim przypadku ,znak barwny” („,colour mark”). Natomiast w rejestrze znaków towarowych polskiego Urzędu Patentowego brak odpowiedników dla tych określeń ${ }^{5}$. Funkcjonuje jedynie 5 kategorii znaków towarowych, tj. znak słowny (S), graficzny $(G)$, dźwiękowy (D), przestrzenny (P), charakterystyczny (C) i kombinacje tych znaków, ewentualnie ,inny typ znaku” (XX). W związku z tym obydwa rodzaje znaków (zarówno zestawienie kolorowych figur geometrycznych, jak też układ kolorów per se) rejestrowane są jako znaki graficzne (G). Nie zawsze więc jest zadaniem łatwym rozróżnienie, $\mathrm{z}$ jakim znakiem mamy do czynienia $\mathrm{w}$ danym przypadku. W takiej sytuacji pomocny jest zawsze opis znaku. W praktyce orzeczniczej można spotkać się z próbą wypełnienia wskazanej luki poprzez stosowanie dla znaków stanowiących kompozycję kolorów per se określenia „znak barwny”, a dla kompozycji kolorystycznej o zadanych kształtach pojęcia „znak graficzny”. Wydaje się, że należałoby postulować de lege ferenda wprowadzenie $\mathrm{w}$ rejestrze krajowych znaków towarowych określeń pozwalających na rozróżnienie wskazanych dwóch różnych kategorii znaków.

\section{Podstawowe warunki rejestracji kompozycji kolorystycznej jako znaku towarowego}

Kompozycja kolorystyczna może uzyskać ochronę w charakterze znaku towarowego, jeśli spełnia warunki określone w definicji znaku towarowego zawarte w ustawie - Prawo własności przemysłowej. Zgodnie z art. 120 ust. 1 p.w.p.

${ }^{5}$ Zob. klasyfikację rodzajów znaków towarowych na stronie internetowej „Bazy Danych UPRP”: https://grab.uprp.pl/PrzedmiotyChronione/Strony\%20witryny/Wyszukiwanie\%20 proste.aspx oraz na stronie wyszukiwarki „Register Plus”: http://regservtd.uprp.pl/register/ application?lng=de\&number=Z.307435

${ }^{6}$ Zob. tak wyrok SN z dnia 2.02.2017 r., ICSK 778/15, LEX 2297410. 
„Znakiem towarowym może być każde oznaczenie, które można przedstawić w sposób graficzny, jeżeli oznaczenie takie nadaje się do odróżnienia towarów jednego przedsiębiorstwa od towarów innego przedsiębiorstwa”. Cytowany przepis odpowiada brzmieniu obowiązującej jeszcze dyrektywy 2008/95/ $\mathrm{WE}^{7}$. Natomiast nie jest w pełni zgodny z postanowieniami nowej dyrektywy 2015/2436. Ustawodawca unijny bowiem w tym ostatnim $\mathrm{z}$ wymienionych aktów prawnych rezygnuje $\mathrm{z}$ wymogu przedstawienia znaku w sposób graficzny, określając jedynie, w sposób ogólny warunki jakie powinno spełniać przedstawienie znaku w rejestrze. W myśl art. 3 dyrektywy 2015/2436: „Znak towarowy może składać się z jakichkolwiek oznaczeń, w szczególności (...), pod warunkiem że oznaczenia takie umożliwiają: a) odróżnianie towarów lub usług jednego przedsiębiorstwa od towarów lub usług innych przedsiębiorstw; oraz b) przedstawienie ich $w$ rejestrze $w$ sposób pozwalający właściwym organom i odbiorcom na ustalenie jednoznacznego i dokładnego przedmiotu ochrony udzielonej właścicielowi tego znaku towarowego.” Zakładając konieczność implementacji postanowień omawianej dyrektywy do prawa polskiego, warto zastanowić się, czy będzie ona wiązała się ze zmianami w odniesieniu do sposobu przedstawienia w zgłoszeniu kompozycji kolorystycznej. W dalszej części tego punku podjęta więc zostanie próba udzielenia odpowiedzi na pytanie, czy fakt rezygnacji z warunku graficznego przedstawienia znaku może wpłynąć na praktykę dotyczącą prezentacji w rejestrze kompozycji kolorów per se.

Jak wynika z cytowanych wyżej norm prawnych kompozycja kolorystyczna, aby mogła uzyskać ochronę w charakterze znaku towarowego, musi spełniać trzy podstawowe warunki, tj.: musi być oznaczeniem, musi nadawać się do odróżniania towarów według kryterium ich pochodzenia oraz de lege lata musi nadawać się do przedstawienia w sposób graficzny, co do 14 stycznia 2019 r. powinno zostać zastąpione wymogiem jednoznacznego i dokładnego przedstawienia znaku zgodnie z wymogami płynącymi z dyrektywy 2015/2436 ${ }^{8}$.

Kompozycja kolorystyczna stanowi oznaczenie, jeśli jest bytem niezależnym od towaru, czyli odznacza się samodzielnością (autonomią) względem towaru, co najmniej na płaszczyźnie pojęciowej. Jak słusznie zauważa R. Skubisz nie jest możliwe, by ten sam przedmiot był jednocześnie obiektem odróżniania i środkiem odróżniania9. Omawiany wymóg samodzielności kompozycji kolorystycznej względem towaru jest spełniony wtedy, gdy kolory nie stanowią właściwości

7 Dyrektywa Parlamentu Europejskiego i Rady 2008/95/WE z dnia 22.10.2008 r. mająca na celu zbliżenie ustawodawstw państw członkowskich odnoszących się do znaków towarowych, Dz.U. C 161, s. 44.

${ }^{8}$ Zob. wyrok TSWE z dnia 6.05.2003 r., w sprawie C-104/01, Libertel Groep BV, pkt 23, wyrok dostępny na stronie internetowej: https://curia.europa.eu/jcms/jcms/j_6/pl/.

9 Zob. R. Skubisz, Glosa do wyroku NSA z dnia 23 listopada 2004 r., GSK 864/04, OSP 2005/9/108, s. 474 . 
towaru ${ }^{10}$. Jako przykład można podać kolor brązowy dla czekolady lub też kolor srebrny/szary dla powierzchni metalowych. Wskazane barwy w takich przypadkach powinny być pozostawione do wolnego użytku wszystkich uczestników obrotu gospodarczego ${ }^{11}$.

Ponadto, kompozycja kolorystyczna de lege lata musi nadawać się do przedstawienia w sposób graficzny. Zgodnie z wytycznymi płynącymi z wyroku w sprawie Sieckmann, znak może zostać przedstawiony graficznie, w szczególności za pomocą obrazów, linii lub symboli, a jego graficzne przedstawienie musi być dokonane w sposób jasny, precyzyjny, samodzielny, łatwo dostępny, zrozumiały, trwały i obiektywny ${ }^{12}$. Jednakże, $w$ dyrektywie 2015/2436 ustawodawca unijny zerwał $\mathrm{z}$ dotychczasową przesłanką graficznego przedstawienia znaku, zastępując ją wymogiem przedstawienia znaku w rejestrze w sposób pozwalający właściwym organom i odbiorcom na ustalenie jednoznacznego i dokładnego przedmiotu ochrony udzielonej właścicielowi danego znaku. Porównując jednak motyw 13 dyrektywy 2015/2436 z przesłankami płynącymi z wyroku w sprawie Sieckmann, wydaje się, że sama idea leżąca u podstaw wymogu prezentacji znaku nie powinna ulec zmianie. Natomiast zmienić się mogą (rozszerzyć) jedynie możliwości techniczne realizacji tej idei. Zgodnie bowiem z motywem 13 dyrektywy, w celu uzyskania pewność prawa oraz prawidłowego administrowania, konieczne jest wprowadzenie wymogu, zgodnie z którym oznaczenie musi być przedstawione w sposób jasny, precyzyjny, samodzielny, łatwo dostępny, zrozumiały, trwały i obiektywny. Do analogicznych wytycznych, dotyczących przesłanki graficznego przedstawienia znaku, odwołał się już w 2002 r. Trybunał Sprawiedliwości, we wspomnianej wyżej, sprawie Sieckmann. Tym samym ustawodawca unijny w dyrektywie 2015/2436 wyraźnie nawiązuje do dotychczasowych wypowiedzi Trybunału Sprawiedliwości i utrwalonej praktyki stosowania prawa.

Natomiast możliwość stosowania nowych technologii w zakresie prezentacji oznaczeń będących znakami towarowymi wynika z motywu 13 dyrektywy 2015/2436, w którym zaznaczono, że jeśli przedstawienie oznaczenia daje zadowalające gwarancje w opisanym zakresie (powołanych wyżej siedmiu wytycznych), należy dopuścić każdą właściwą formę tego przedstawienia wykorzystującą ogólnie dostępną technologię, a więc niekoniecznie formę graficzną. Co do zasady więc w przypadku znaków graficznych (postrzeganych za pomocą zmysłu wzroku) wskazana nowelizacja nie powinna wiązać się z istotnymi zmianami $\mathrm{w}$ zakresie formy ich przedstawienia. Zmiany takie natomiast $\mathrm{z}$ pewnością będą dotyczyły możliwości przedstawienia w rejestrze tzw. znaków niekonwencjo-

10 Ibidem.

11 Zob. tak m.in. M. Kicia, (w:) Kolor per se jako znak towarowy w świetle orzecznictwa europejskiego, „Rzecznik Patentowy”, 2004/1-2, s. 117.

${ }^{12}$ Wyrok TSWE z dnia 12.12.2002 r., w sprawie C-273/00, Sieckmann, pkt 55 oraz wyrok w sprawie Libertel, pkt 68, wyroki dostępne na stronie internetowej: https://curia.europa.eu/jcms/jcms/j_6/pl/. 
nalnych (tj. np. dźwiękowych, ruchomych, multimedialnych, zapachowych, czy smakowych). Wnioski te zdaje się potwierdzać brzmienie art. 3 ust. 3 rozporządzenia wykonawczego 2017/1431 ${ }^{13}$, w którym określone zostały szczegółowo wymogi dotyczące przedstawienia w rejestrze poszczególnych kategorii znaków towarowych UE. Choć wskazane rozporządzenie zawiera przepisy wykonawcze odnoszące się do regulacji prawnej dotyczącej znaku towarowego UE (de lege lata jest to rozporządzenie $2017 / 1001^{14}$ ), to należy zauważyć, że w kwestii związanej $\mathrm{z}$ warunkami prezentacji znaku $\mathrm{w}$ rejestrze, postanowienia rozporządzenia 2017/1001 są analogiczne do tych zawartych w dyrektywie 2015/2436. Tym samym wytyczne płynące z powołanego wyżej rozporządzenia wykonawczego (uszczegółowiające zasady prezentacji znaku w rejestrze) mogą stanowić pewne wskazówki odnośnie do interpretacji przepisów dyrektywy 2015/2436 w danym zakresie.

Przykładowo znak multimedialny, czyli taki który składa się z zestawienia obrazu i dźwięku lub obejmuje takie zestawienie, zgodnie z art. 3 ust. 3 lit. i) rozporządzenia 2017/1431, przedstawia się poprzez złożenie pliku audiowizualnego zawierającego zestawienie obrazu i dźwięku. Natomiast znak towarowy składający się wyłącznie z zestawienia kolorów bez konturów, przedstawia się poprzez złożenie reprodukcji pokazującej systematyczne ułożenie zestawienia kolorów w jednorodny i z góry ustalony sposób wraz ze wskazaniem tych kolorów poprzez odniesienie do powszechnie uznanego kodu koloru, co wyraźnie wynika z art. 3 ust. 3 lit f) rozporządzenia 2017/1431. Zgodnie $\mathrm{z}$ wymienionym przepisem można również dodać opis systematycznego ułożenia kolorów. Przedstawione reguły prezentacji znaku towarowego realizują wytyczne płynące $\mathrm{z}$ dotychczasowych wyroków Trybunału Sprawiedliwości. Już bowiem w 2003 r. w sprawie Libertel Trybunał Sprawiedliwości podkreślił, że w odniesieniu do rejestracji koloru jako takiego konieczne jest określenie tegoż koloru za pomocą międzynarodowej klasyfikacji kolorów ${ }^{15}$, a następnie w wyroku w sprawie Heidelberger potwierdził wyraźnie w odniesieniu do kompozycji kolorystycznej, że oprócz podania słownej nazwy koloru i jego numeru według określonej międzynarodowej klasyfikacji kolorów, konieczne jest określenie stałego sposobu połączenia barw ${ }^{16}$.

Tytułem przykładu można podać, że opisanych wymogów graficznego przedstawienia znaku nie spełnia abstrakcyjne połączenie dwóch lub więcej kolorów,

${ }^{13}$ Rozporządzenie wykonawcze Komisji (UE) 2017/1431 z dnia 18.05.2017 r. określające szczegółowe zasady wykonania niektórych przepisów rozporządzenia Rady (WE) nr 207/2009 w sprawie znaku towarowego Unii Europejskiej (Dz.U. UE L 78 z 24.03.2009, s. 1), którego postanowienia stosowane są od dnia 1 października $2017 \mathrm{r}$.

${ }^{14}$ Rozporządzenie Parlamentu Europejskiego i Rady (UE) 2017/1001 z dnia 14.06.2017 r. w sprawie znaku towarowego Unii Europejskiej (Dz.U. UE L 154 z 16.06.2017 r., s. 1).

${ }^{15}$ Wyrok w sprawie Libertel, pkt 68.

${ }^{16}$ Wyrok TSWE z dnia 24.06.2004 r. w sprawie C-49/02, Heidelberger Bauchemie GmbH, pkt 42, wyrok dostępny na stronie internetowej: https://curia.europa.eu/jcms/jcms/j_6/pl/. 
tj. bezkształtne i pozbawione jakiejkolwiek formy zestawienie kolorystyczne, jak w przypadku znaku towarowego Unii Europejskiej (dalej ZTUE) zgłoszonego za nr 1419555 przez Deutsche Post $A G^{17}$. Opis tego znaku zawierał informację, zgodnie z którą „Wnosi się o ochronę kombinacji koloru żółtego/niebieskiego/ czerwonego jako kombinacji osobnych kolorów w jakimkolwiek ich zestawieniu:, żółty: HKS 4, niebieski: Pantone 280, czerwony: HKS 14".
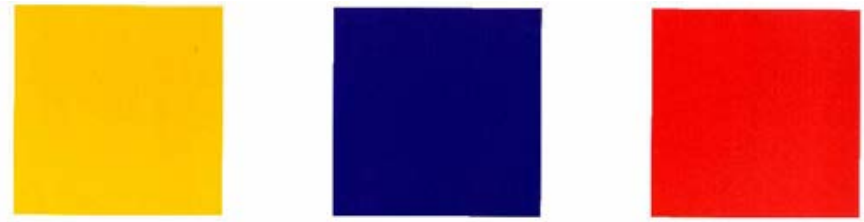

rys. 1 ZTUE nr 1419555, zgłaszający: Deutsche Post AG

Ponadto jak wynika z decyzji EUIPO, wymienionych wyżej warunków nie spełniał znak towarowy Unii Europejskiej zgłoszony za nr 3075819 jako znak barwny („colour mark”) ${ }^{18}$. W opisie tego znaku stwierdzono jedynie, że „Wnioskuje się o ochronę dla koloru niebieskiego (RAL 5002), srebrnego (RAL 9006) i czerwonego (RAL 3027)", a sam znak został przedstawiony graficznie w sposób zobrazowany poniżej. Wprawdzie, w przeciwieństwie do opisu poprzedniego znaku, w opisie tego oznaczenia nie było mowy o tym, że wnosi się o ochronę wskazanych kolorów w każdej możliwej ich kombinacji, to jednak cytowany opis był zdecydowanie zbyt ogólny. Brakowało w nim bowiem wyraźnego określenia sposobu połączenia kolorów, zgodnie z wytycznymi płynącymi z prejudycjalnego wyroku Trybunału Sprawiedliwości w sprawie Heidelberger, w którym organ orzekający uznał, że wniosek o rejestrację znaku stanowiącego kompozycję kolorów per se ma zawierać „dokładne dyspozycje dotyczące określonego z góry i stałego sposobu połączenia kolorów"19.

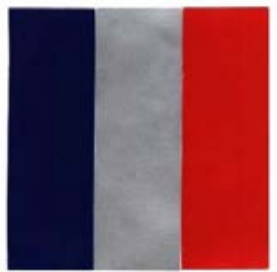

rys. 2 ZTUE nr 3075819, zgłaszający: Red Bull GmbH

${ }_{17}$ Decyzja Czwartej Izby Odwoławczej OHIM z dnia 27.07.2004 r., w sprawie R 730/2001-4, pkt 19,20.

${ }^{18}$ Decyzja Izby Unieważnień OHIM z dnia 9.10.2013 r., w sprawie 5938 C, pkt 44.

${ }_{19}$ Wyrok w sprawie Heidelberger, pkt 42. 
$\mathrm{Na}$ analogiczne wymogi dotyczące przedstawienia kompozycji kolorystycznej wskazują również orzeczenia polskich sądów, czego przykładem może być wyrok NSA wydany w sprawie znaku towarowego stanowiącego zestawienie koloru białego i pomarańczowego ${ }^{20}$. Zgodnie $\mathrm{z}$ tym, co wynika $\mathrm{z}$ lektury wspomnianego wyroku, spółka Ferrero S.P.A. ubiegała się o uzyskanie w Polsce uznania międzynarodowej rejestracji znaku towarowego graficznego, występującego w postaci dwubarwnej kompozycji (dolna część pomarańczowa, górna zaś biała), objętego rejestracją nr IR 667827 z 2 XII 1996 r. $^{21}$ Tak przedstawione oznaczenie zdaniem NSA jest „nie w pełni skonkretyzowane i niejednoznaczne”. Opis natomiast jest nieprecyzyjny, gdyż nie zawiera pełnej informacji odnośnie do tego, jak przebiega linia oddzielająca kolor biały od pomarańczowego (czy jest to linia prosta czy krzywa) oraz nie określa proporcji pomiędzy tymi dwoma kolorami. Nie zostały wiec spełnione wszystkie wytyczne dotyczące przedstawienia znaku określone najpierw we wspomnianym wyżej wyroku w sprawie Sieckmann, a następnie Heidelberger. Należy zgodzić się z NSA, że „proste zestawienie przez przedsiębiorcę dwóch kolorów z ograniczonego zestawu widzialnych barw nie powinno być wykorzystywane jako znak towarowy. Wówczas, przy ograniczonej liczbie kolorów, inni producenci używający tych kolorów w dobrej wierze byliby ograniczani w możliwości prowadzenia działalności gospodarczej".

Z kolejnego orzeczenia polskiego sądu wynika, że nie wystarczy określenie proporcji, w jakich występują zestawione kolory dla właściwego graficznego przedstawienia znaku będącego kompozycją kolorystyczną. Konieczne jest również określenie wzajemnego położenia tych kolorów ${ }^{22}$. Zgodnie bowiem z tym, co stwierdził Sąd Najwyższy w sprawie dotyczącej znaku towarowego Red Bull: „Bezkonturowy znak towarowy składający się z dwóch barw: srebrnej i niebieskiej w każdej możliwej formie (układzie), jedynie w proporcji około 50:50 nie miałby zdolności odróżniającej pozwalającej grupie odbiorców towarów (napojów energetycznych) rozróżnić pochodzenie tych towarów."

20 Wyrok NSA z dnia 23.11.2004 r. (GSK 864/04), OSP 2005/9/108, LEX nr 154047 z glosą R. Skubisza.

${ }^{21}$ Niemożliwe jest zamieszczenie w niniejszym opracowaniu przedstawienia graficznego znaku IR 667827, gdyż pod wskazanym numerem w bazie znaków towarowych (http://www.wipo. int/romarin/result.xhtml) widnieje znak odmienny od znaku opisanego w omawianej sprawie, tj. znak w postaci pojedynczego koloru czerwonego.

${ }^{22}$ Wyrok SN z dnia 2.02.2017 r. (I CSK 778/15), LEX nr 2297410. 


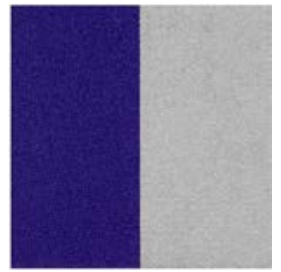

rys. 3 znak towarowy krajowy R. 256029, zgłaszający: Red Bull GmbH

Powołany wyrok w pełni harmonizuje z wytycznymi płynącymi z wyroku Sądu, który zapadł kilka miesięcy później w połączonych sprawach dotyczących unieważnienia praw do dwóch analogicznie zobrazowanych znaków towarowych UE zarejestrowanych również na rzecz Red Bull GmbH ${ }^{23}$. W przypadku pierwszego znaku w piśmie dołączonym do zgłoszenia określono, że „Żądana ochrona obejmuje kolory niebieski (RAL 5002) i srebrny (RAL 9006). Proporcja kolorów wynosi około 50\%-50\%", a w odniesieniu do drugiego znaku w zgłoszeniu wskazano na kolor „niebieski (Pantone 2747 C), srebrny (Pantone 877 C)”, a także dołączono następujący opis: „Oba kolory będą stosowane w równych proporcjach oraz zostaną zestawione”. Sąd oddalił skargę spółki Red Bull GmbH na decyzję Izby Odwoławczej EUIPO, w której oddaliła ona skargę na decyzję Wydziału Unieważnień EUIPO w przedmiocie unieważnienia prawa do obu wspomnianych znaków towarowych UE. Sąd uznał bowiem, że „przedstawienie graficzne dwóch lub większej liczby kolorów wskazanych w sposób abstrakcyjny i bez konturów powinno obejmować systematyczny układ łączący dane kolory w określony z góry i stały sposób" ${ }^{24}$, potwierdzając tym samym opinię wyrażoną przez Trybunał w sprawie Heidelberger ${ }^{25}$. Zdaniem Sądu wskazanie proporcji kolorów w opisie spornych znaków towarowych nie było wystarczające dla spełnienia wymogu istnienia takiego systematycznego układu.

Omawiając wymogi dotyczące przedstawienia kompozycji kolorystycznej per se, należy ponadto zwrócić uwagę na to, że ustawodawca unijny w rozporządzeniu 2017/1431, w odniesieniu do znaku stanowiącego kompozycję kolorystyczną, mówi jedynie o konieczności złożenia reprodukcji pokazującej owo zestawienie kolorów, nie odwołując się do pojęcia „reprodukcji graficznej”. Nie można jednak, jak się wydaje, tego sformułowania wiązać z możliwością całkowitej rezygnacji ze zobrazowania zestawienia kolorów, na rzecz samego opisu, ze względu na to, że jest to kategoria znaków postrzeganych za pomocą zmysłu wzroku. Sformułowanie to natomiast daje możliwość posłużenia się innymi - niż

${ }^{23}$ Wyrok Sądu z 30.11.2017 r. w sprawach połączonych T101/15 i T102/15, Red Bull GmbH v. EUIPO, wyrok dostępny na stronie internetowej: https://curia.europa.eu/jcms/jcms/j_6/pl/.

${ }^{24}$ Wyrok w sprawie Red Bull GmbH, pkt 47.

${ }^{25}$ Wyrok w sprawie Heidelberger Bauchemie GmbH, pkt. 42 
tylko graficzne przedstawienie - formami obrazowej reprodukcji analizowanej kategorii znaków. W związku z tym wydaje się, że pod pojęciem „reprodukcji znaku składającego się z zestawienia kolorów bez konturów" należy rozumieć np. możliwość przedstawienia takiego znaku w postaci zarówno rysunku, jak i zdjęcia, czy nawet próbki materiału. Możliwości takie będą jednak mogły zostać dopuszczone dopiero po przeprowadzeniu implementacji przepisów dyrektywy 2015/2436 do prawa polskiego.

Ostatnim z wymienionych wyżej podstawowych wymogów, jaki musi spełniać kompozycja kolorystyczna, aby mogła uzyskać ochronę w charakterze znaku towarowego jest zdolność do odróżniania towarów według kryterium ich pochodzenia $\mathrm{z}$ danego przedsiębiorstwa. Wspomniana zdolność odróżniania towarów powinna być realizowana zarówno w sensie abstrakcyjnym (co wynika z art. 120 ust. 1 p.w.p. oraz art. 3 dyrektywy 2015/2436), jak i konkretnym (zob. art. $129^{1}$ ust. 1 pkt 2-4 p.w.p. oraz art. 4 ust. 1 lit. b) - d) dyrektywy 2015/2436). W pierwszym przypadku chodzi o to, by owa kompozycja kolorystyczna nadawała się do przekazywania informacji o pochodzeniu towarów (usług) w odniesieniu do jakiejkolwiek kategorii towarów (usług). Abstrakcyjną zdolność odróżniającą należy bowiem badać w oderwaniu od konkretnego rodzaju towarów, jako że wyraża się ona w potencjalnej zdolności danego oznaczenia do odróżniania towarów lub usług w ogóle jako takich ${ }^{26}$. Ze względu na dopuszczalność rejestracji kompozycji kolorów per se zarówno w rejestrze prowadzonym przez UPRP jak i EUIPO, należy uznać, że generalnie kompozycja kolorystyczna posiada pierwotną zdolność odróżniającą 27 . Trybunał Sprawiedliwości zwrócił uwagę na to, że kolor jako taki, nieokreślony przestrzennie, może mieć charakter odróżniający w rozumieniu art. 3 ust. 1 lit. b) i art. 3 ust. 3 dyrektywy ${ }^{28}$, pod warunkiem w szczególności, iż może on być przedmiotem przedstawienia $\mathrm{w}$ formie graficznej, które jest jasne, precyzyjne, samo w sobie kompletne, łatwo dostępne, zrozumiałe, trwałe i obiektywne ${ }^{29}$. Jak już była o tym mowa, wymienione wymogi są spełnione w przypadku znaku stanowiącego kompozycję kolorów per se, jeśli w opisie takiego znaku podana zostanie słownie nazwa koloru i jego

${ }^{26}$ Zob. R. Skubisz, Zdolność odróżniająca znaku towarowego w orzecznictwie Trybunału Sprawiedliwości Wspólnot Europejskich, w: „Biuletyn Politechniki Świętokrzyskiej”, red. A. Adamczak, Kielce 2005, z. 29, s. 115; U. Promińska, w: E. Nowińska, U. Promińska, M. du Vall, Prawo własności przemysłowej, Warszawa 2008, s. 187.

${ }^{27}$ Zob. podobnie w odniesieniu do pojedynczego koloru M. Mazurek, Rejestracja pojedynczego koloru jako znaku towarowego, PIPWI UJ 2004/86, s. 237.

${ }^{28}$ Pierwsza dyrektywa Rady WE nr 89/104/EWG z dnia 21.12.1988 r. mająca na celu zbliżenie ustawodawstw państw członkowskich odnoszących się do znaków towarowych (Dz. Urz. WE z 1989 r., nr L 40, s. 1).

${ }^{29}$ Wyrok TSWE z dnia 12.12.2002 r., w sprawie C-273/00, Sieckmann, pkt 55 oraz wyrok w sprawie Libertel, pkt 68, wyroki dostępne na stronie internetowej: https://curia.europa.eu/jcms/jcms/j_6/pl/. 
numer według międzynarodowej klasyfikacji kolorów oraz określony zostanie z góry stały sposób połączenia kolorów ${ }^{30}$.

Ponadto kompozycja kolorystyczna powinna cechować się konkretną zdolnością odróżniającą, która badana jest w odniesieniu do konkretnych towarów, dla jakich znak został zgłoszony do ochrony ${ }^{31}$. W tym kontekście istotny jest nie tylko sposób prezentacji układu barw, ale również dobór właściwych kolorów względem towarów, jakie mają one sygnować. W niektórych przypadkach brak konkretnej zdolności odróżniającej koloru może wynikać z tego, że stanowi on informację o właściwościach sygnowanego nim towaru. Przykładowo kolor czerwony na przewodach, w przypadku prądu stałego, oznacza przewód z potencjałem „,", kolor niebieski stosuje się dla przewodów neutralnych, a kolor zielony dla przewodów ochronnych. Ponadto kolor zielony może oddawać pewne właściwości towarów (np. na produktach żywnościowych może być symbolem smaku miętowego, a na towarach ogrodniczych lub rolniczych może być nośnikiem informacji o powiązaniu danego towaru z przyrodą).

W związku z tym nie powinna dziwić odmowa udzielenia prawa ochronnego na znak towarowy przedstawiający kolor zielony per se zgłoszony dla rur służących do przepływu wody ${ }^{32}$. Wojewódzki Sąd Administracyjny we wskazanej sprawie stwierdził wprost, że: ,istnieje niebezpieczeństwo iż będzie się on kojarzył z przyrodą, przez co jest kolorem, który nie powinien zostać zmonopolizowany przez jedno przedsiębiorstwo, zwłaszcza, iż przybrany odcień zielonego RAL 1504060 nie jest oryginalny." Ponadto sąd dodał, że brak zdolności odróżniającej koloru zielonego w przedstawionej sprawie dodatkowo wynika z tego, że powszechnie używa się koloru zielonego dla wody oraz wodnych roztworów związków chemicznych nie stwarzających dla obsługi zagrożenia chemicznego i termicznego.

Na podobne okoliczności uzasadniające brak zdolności odróżniającej koloru jako takiego, zwrócił uwagę Trybunał Sprawiedliwości w sprawie dotyczącej rejestracji koloru pomarańczowego per se m.in. dla urządzeń do obróbki nasion (klasa 11) oraz produktów rolnych, ogrodniczych i leśnych (klasa 31). Organ orzekający uznał, że używanie kolorów, w tym wnioskowanego odcienia oranżu lub odcieni bardzo zbliżonych, nie jest rzadkością w odniesieniu do wymienionych towarów, a zainteresowana strona nie przedstawiła okoliczności pozwalających na stworzenie kategorii towarów, dla których pewne kolory nie byłyby powszechnie używane ${ }^{33}$.

${ }^{30}$ Wyrok w sprawie Heidelberger, pkt 42.

${ }^{31}$ Zob. R. Skubisz, Zdolność odróżniająca znaku towarowego w orzecznictwie ..., . s. 115-117; K. Szczepanowska-Kozłowska, (w:) System Prawa Prywatnego. Prawo własności przemysłowej, red. R. Skubisz, T. 14B, Warszawa 2012, s. 576; wyrok NSA z 09.092008 r. (II GSK 334/08), LEX nr 489168.

${ }^{32}$ Wyrok WSA w Warszawie z dnia 3.12.2009 r. (VI SA/Wa 1452/09), LEX nr 1814217.

${ }^{33}$ Wyrok TSWE z dnia 21.10.2004 r., w sprawie C447/02 P, KWS Saat AG v. OHIM, pkt 79, 81, wyrok dostępny na stronie internetowej: https://curia.europa.eu/jcms/jcms/j_6/pl/. 
Analogiczne przyczyny stanowiły uzasadnienie dla odmowy zarejestrowania znaku towarowego w postaci koloru zielonego, zgłoszonego dla maszyn rolni$\mathrm{czych}^{34}$. W sprawie tej urząd uznał, że skoro jest to kolor charakterystyczny dla działalności związanej z przyrodą, nie może być on oznaczeniem charakterystycznym wyłącznie dla towarów danego przedsiębiorcy i trudno się spodziewać, by był postrzegany przez odbiorców jako wskazówka pochodzenia towarów od określonego przedsiębiorstwa.

Jednakże już połączenie kolorów zielonego i żółtego dla maszyn rolniczych (w tym traktorów) okazało się na tyle charakterystyczne, że znakowi takiemu przyznano zdolność odróżniającą i dokonano jego rejestracji ${ }^{35}$. Ustaleń tych nie zdołała podważyć strona wnosząca o unieważnienie prawa do wskazanego znaku $^{36}$. Omawiany znak został zgłoszony za $\mathrm{nr} 000063289$ i przedstawiony $\mathrm{w}$ rejestrze $\mathrm{w}$ postaci prostokąta, przedzielonego na pół linią poziomą przechodzącą przez środek prostokąta, dzielącą go na dwa pola, z których górne jest koloru zielonego, a dolne żółtego. W opisie znaku zamieszczono informację, zgodnie z którą kolory objęte wnioskiem o rejestrację zostały oznaczone zgodnie z systemem Munsella: 9.47 GY3.57/7.45 (zielony) i 5.06 Y7.63/10.66 (żółty). Ponadto w opisie wyjaśniono, że: „nadwozie pojazdu jest zielone [i że] koła są żółte".

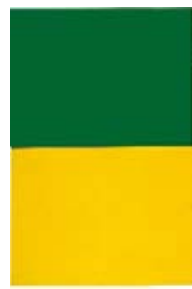

rys. 4 ZTUE nr 000063289, uprawniony: Deere \& Company

Opisane przykłady graficznej prezentacji kompozycji kolorystycznej per se wskazują na to, że kluczem do właściwego przedstawienia w rejestrze znaku towarowego stanowiącego kompozycję kolorów jako takich jest przede wszystkim opis znaku. W przypadku bowiem zobrazowania znaku jedynie poprzez przedstawienie kolorowych prostokątów, dopiero ich opis pozwala na wyraźne określenie sposobu połączenia kolorów, ich wzajemnych proporcji i położenia, a tym samym zakresu prawa wyłącznego. Konieczne jest jasne, precyzyjne, samo w sobie kompletne, łatwo dostępne, zrozumiałe, trwałe i obiektywne

${ }^{34}$ Znak zgłoszony za nr 000469213 na rzecz CLAAS KGaA mbH, decyzja OHIM o odmowie rejestracji $\mathrm{z}$ dnia $28.01 .2000 \mathrm{r}$.

${ }^{35}$ Wyrok TSWE z dnia 28.10.2009 r., w sprawie T137/08, BCS SpA v. Deere \& Company, wyrok dostępny na stronie internetowej: https://curia.europa.eu/jcms/jcms/j_6/pl/.

${ }^{36}$ Ibidem. 
przedstawienie kompozycji kolorów, aby można było mówić o oznaczeniu, które zdolne jest do pełnienia podstawowej funkcji znaku towarowego, jaką jest wskazywanie na pochodzenie towarów z określonego przedsiębiorstwa. Każde dowolne zestawienie dwóch lub więcej kolorów pojawiające się w różnych konfiguracjach nie byłoby zdolne do pełnienia takiej funkcji.

\section{Zakres przedmiotowy prawa wyłącznego do znaku towarowego stanowiącego kompozycję kolorystyczną}

Zakres prawa wyłącznego do znaku towarowego w sensie pozytywnym wyznacza art. 153 ust. 1 p.w.p., zgodnie z którym przez uzyskanie prawa ochronnego nabywa się prawo wyłącznego używania znaku towarowego w sposób zarobkowy lub zawodowy na całym obszarze Rzeczypospolitej Polskiej. W dyrektywie 2015/2436 zagadnienie to zostało uregulowane w sposób bardzo lakoniczny. W art. 10 ust. 1 dyrektywy 2015/2436 mowa jest bowiem jedynie o tym, że rejestracja znaku towarowego skutkuje przyznaniem właścicielowi wyłącznego prawa do tego znaku. Ponadto na stronę pozytywną prawa do znaku składa się możność rozporządzania prawem ochronnym na znak towarowy, co wynika z art. 162 i 163 p.w.p. oraz odpowiednio z art. 22 i 25 dyrektywy 2015/2436.

Wśród przepisów ustawy - Prawo własności przemysłowej zakazową stronę prawa podmiotowego do znaku towarowego pozwala określić art. 296 p.w.p., w którym ustawodawca wyliczył roszczenia służące uprawnionemu, na wypadek wkroczenia przez naruszyciela w zakres prawa wyłącznego przysługującego uprawnionemu oraz określił, kiedy dochodzi do naruszenia prawa wyłącznego do znaku towarowego ${ }^{37}$. W myśl art. 296 ust. 2 p.w.p. do naruszenia prawa ochronnego na znak towarowy dochodzi, gdy osoba trzecia bezprawnie używa w obrocie gospodarczym:

1) znaku identycznego do zarejestrowanego znaku towarowego w odniesieniu do identycznych towarów;

2) znaku identycznego lub podobnego do zarejestrowanego znaku towarowego w odniesieniu do towarów identycznych lub podobnych, jeżeli zachodzi

${ }^{37}$ Zob. tak na gruncie ustawy o znakach towarowych R. Skubisz, Prawo z rejestracji znaku towarowego i jego ochrona. Studium z zakresu prawa polskiego na tle prawno-porównawczym, Lublin 1988, s. 76-79; R. Skubisz, Prawo znaków towarowych. Komentarz, Warszawa 1997, s. 127; U. Promińska, Ustawa o znakach towarowych. Komentarz, Warszawa 1998, s. 54 oraz na gruncie ustawy - p.w.p. m.in. J. Szwaja, E. Wojcieszko-Głuszko, I.B. Mika, Kumulacja praw własności przemysłowej w prawie polskim (na przykładzie wzorów przemysłowych i znaków towarowych), KPP 2001/2, s. 365; M. Trzebiatowski, (w:) System Prawa Prywatnego. Prawo własności przemysłowej, red. R. Skubisz, T. 14B, Warszawa 2012, s. 780. 
ryzyko wprowadzenia odbiorców w błąd, które obejmuje w szczególności ryzyko skojarzenia znaku ze znakiem towarowym zarejestrowanym;

3) znaku identycznego lub podobnego do renomowanego znaku towarowego, zarejestrowanego w odniesieniu do jakichkolwiek towarów, jeżeli takie używanie może przynieść używającemu nienależną korzyść lub być szkodliwe dla odróżniającego charakteru bądź renomy znaku wcześniejszego.

Na gruncie przepisów dyrektywy 2015/2436 strona zakazowa prawa podmiotowego do znaku towarowego określona została $\mathrm{w}$ art. 10 ust. 2, zgodnie z którym właściciel znaku jest uprawniony do zakazania wszelkim osobom trzecim, które nie posiadają jego zgody, używania w obrocie handlowym wymienionych w dyrektywie oznaczeń, których warunki używania scharakteryzowane zostały w sposób analogiczny jak w cytowanym wyżej art. 296 ust. 2 p.w.p.

Porównując stronę pozytywną z zakazową stroną prawa podmiotowego do znaku towarowego w świetle obwiązujących przepisów ustawy - Prawo własności przemysłowej należy stwierdzić, że szerszy zakresu uprawnień wynika z zakazowej strony tego prawa ${ }^{38}$. Strona pozytywna prawa do znaku towarowego obejmuje bowiem jedynie znak w postaci zgłoszonej do ochrony dla wymienionych w zgłoszeniu kategorii towarów lub usług. Natomiast strona zakazowa analizowanego prawa podmiotowego rozciąga się również na oznaczenia podobne, używane dla podobnych towarów. Ponadto, zgodnie z art. 296 ust. 2 pkt 3 p.w.p. ustawodawca jeszcze bardziej rozszerzył zakres przedmiotowy strony zakazowej prawa ochronnego na znak towarowy w odniesieniu do znaków renomowanych, które chronione są poza zasadą specjalizacji, tj. dla jakichkolwiek towarów ${ }^{39}$. W odniesieniu natomiast do przepisów dyrektywy 2015/2436, biorąc pod uwagę bardzo lakoniczne brzmienie art. 10 ust. 1, należałoby wręcz stwierdzić, że co do zasady zakres uprawnień właściciela znaku towarowego wynika z przepisów kształtujących zakazową stronę prawa podmiotowego.

Celem rozważań podejmowanych w dalszej części artykułu jest zbadanie, na przykładzie konkretnych rozstrzygnięć, w jakim zakresie uprawniony do znaku stanowiącego kompozycję kolorystyczną może domagać się ochrony swojego prawa. Warto przeanalizować, czy ze względu - na opisaną wyżej - specyfikę znaków towarowych stanowiących kompozycję kolorystyczną, ich ochrona w odniesieniu do znaków podobnych jest analogiczna do tej właściwej dla standardowych znaków graficznych (określanych, w rejestrze EUIPO mianem

${ }^{38}$ Zob. tak na gruncie ustawy o znakach towarowych R. Skubisz, Prawo z rejestracji ..., s. 80; R. Skubisz, Prawo znaków ..., s. 127; U. Promińska, Ustawa o znakach ..., s. 54.

${ }^{39}$ Zob. J. Szwaja, E. Wojcieszko-Głuszko, I.B. Mika, Kumulacja praw ..., s. 365; ; M. Trzebiatowski, (w:) System, Tom 14B ..., s. 797 oraz szerzej na temat ochrony znaków towarowych poza zasadą specjalizacji: J. Sitko,Trade marks with a reputation and famous marks: differences in approach between the European Union, Poland and the United States in relation to the principle of speciality, Queen Mary Journal of Intellectual Property (Queen Mary University of London) 2017/7, s. 331 i n. 
"figurative marks"), czy też zachowuje pewne odmienności. Jest to kwestia bardzo istotna ze względu na ryzyko monopolizacji rynku w danej dziedzinie w przypadku zbyt liberalnego podejścia do ochrony takich znaków. Paleta kolorów, które przeciętny człowiek potrafi wyodrębnić według ich nawy (z pominięciem subtelności związanych z odcieniami, których są dziesiątki, jeśli nie setki) jest bowiem bardzo ograniczona.

W kontekście ochrony znaku będącego kompozycją kolorystyczną przed ryzykiem wprowadzenia w błąd, interesujące spostrzeżenia poczynił Sąd Najwyższy w sprawie odnoszącej się do ochrony kompozycji koloru żółtego i zielonego, zarejestrowanej na rzecz właściciela Stacji paliw BP P.L.C. ${ }^{40}$

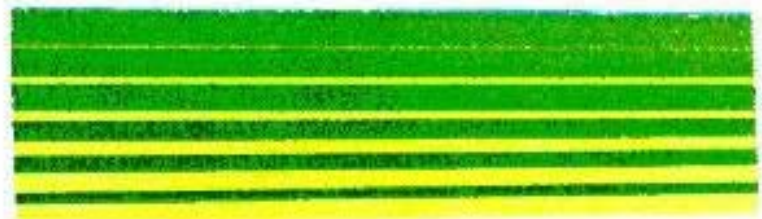

rys. 5 Znak zgłoszony do UPRP dnia 20.09.1995 r., nr prawa ochronnego: R. 115856, uprawniony: BP P.L.C., kl. 42.

W sprawie tej powód w sposób bardzo ogólnikowy przedstawił w pozwie swoje żądanie, domagając się nakazania pozwanemu zaprzestania używania zielono-żółtej kombinacji kolorów dla oznakowania jego stacji paliw, usług przez niego świadczonych, ich reklamy i sprzedaży, a także zaprzestania oświetlania na zielono wszelkich elementów jego stacji paliw. Ze względu na brak jakichkolwiek szczegółowych wytycznych dotyczących użycia wskazanego zestawu kolorów, należy przyjąć, że żądanie dotyczyło zakazu używania przez pozwanego kompozycji kolorów zielonego i żółtego w jakiejkolwiek postaci, formie czy proporcjach ${ }^{41}$. Sąd Najwyższy słusznie skonstatował, że skoro w sprawie tej przedmiotem ochrony była określona kombinacja barw, używana przez powoda, jasne jest, że ochrona, której żądał powód nie obejmuje każdej kombinacji kolorystycznej składającej się z kolorów zawartych w używanym przez niego oznaczeniu, a tylko takie zestawienie barw, które może wprowadzić w błąd co do oznaczenia przedsiębiorstwa, towaru lub usługi ${ }^{42}$. Warto dodać, że Sąd Najwyższy przekazując sprawę Sądowi Administracyjnemu do ponownego rozpatrzenia, stwierdził jednocześnie konieczność zredukowania żądań pozwu, co spotkało

\footnotetext{
${ }^{40}$ Wyrok SN z dnia 3.06.2009 r. (IV CSK 61/09), LEX nr 511987, OSP 2010/12/124.

${ }^{41}$ Zob. tak G. Tylec, Glosa do wyroku SN z dnia 3.06.2009 r. (IV CSK 61/09), OSP 2010/12/124, s. 890 .

${ }^{42}$ Wyrok SN z dnia 3.06.2009 r. (IV CSK 61/09), LEX nr 511987, OSP 2010/12/124.
} 
się z krytycznymi głosami w doktrynie ${ }^{43}$. Sąd Apelacyjny w rezultacie zmienił zaskarżony wyrok w ten sposób, że nakazał pozwanemu zaprzestania stosowania koloru zielonego na wymienionych w wyroku budowlach i elementach stanowiących wyposażenie stacji benzynowej pozwanego.

W kolejnym rozstrzygnięciu tej samej sprawy, która ponownie wróciła przed Sąd Najwyższy, organ orzekający jeszcze raz uchylił wyrok Sądu Apelacyjnego dochodząc do wniosku, że „ochrona nie może być udzielona jedynie kolorowi zielonemu będącemu elementem składowym znaku towarowego, którego dotyczy ochrona. Kolor ten od początku procesu był łączony z kolorem żółtym, zatem nie ma powodu, aby pozwany nie mógł zastosować koloru zielonego w połączeniu z innymi kolorami”" ${ }^{\prime 4}$. Należy zgodzić się z tym zapatrywaniem, gdyż na podstawie art. 153 ust. 1 p.w.p. nabywa się prawo wyłączne do używania danego znaku towarowego jako całości, co nie może być rozumiane jako przyznanie prawa do poszczególnych elementów danego znaku rozpatrywanych osobno.

Ponadto Sąd Najwyższy słusznie zauważył, że jeśli tylko jednemu przedsiębiorcy przyznany zostałby monopol na używanie określonego koloru (co przejawiałoby się w możliwości zakazania używania danego koloru innym przedsiębiorcom prowadzącym ten sam rodzaj działalności), to doszłoby do istotnego ograniczenia swobody podejmowania i prowadzenia działalności gospodarczej oraz do naruszenia zasad swobodnej (uczciwej) konkurencji, zwłaszcza w sytuacji, gdy na danym rynku jest zainteresowanie tylko kilkoma kolorami.

Na marginesie warto nadmienić, że wskazane zapatrywanie zdaje się potwierdzać również decyzja Urzędu Patentowego RP odmawiająca udzielenia prawa ochronnego na znak towarowy w postaci koloru zielonego per se na rzecz spółki BP. P.L.C. dla towarów m.in. w kl. 4 (m.in. paliwa, oleje, smary) ${ }^{45}$. Należy jednak podkreślić, że przedstawionej tezy nie można utożsamiać z całkowitym brakiem możliwości uzyskania rejestracji pojedynczego koloru jako takiego w charakterze znaku towarowego. Kolor per se może uzyskać ochronę jako znak towarowy, czego dowodami są rejestracje dokonane w EUIPO, np. rejestracja „koloru magenta” dla usług telekomunikacyjnych (znak towarowy Unii Europejskiej nr 000212787) na rzecz Deutsche Telekom AG, czy rejestracja „koloru lilowego/fioletowego" dla czekolad i pralin (znak towarowy Unii Europejskiej nr 00031336) na rzecz Kraft Foods Schweiz Holding GmbH. Jednakże są to sytuacje bardzo rzadkie. Niezwykle trudno bowiem wykazać zdolność odróżniającą

${ }^{43}$ Zob. tak G. Tylec, Glosa do wyroku SN z dnia 3.06.2009 r. (IV CSK 61/09), OSP 2010/12/124, s. 891.

${ }^{44}$ Wyrok SN z dnia 21.10.2010 r. (IV CSK 231/10), LEX nr 688516.

${ }_{45}$ Znak zgłoszony do UPRP dnia 21.02.2002 r., za numerem Z. 246785, informacja o odmowie rejestracji zob. strona internetowa: https:/grab.uprp.pl/PrzedmiotyChronione/Strony\%20witryny/ Wyszukiwanie\%20proste.aspx 
pojedynczego koloru. Znacznie więcej jest przykładów decyzji odmawiających rejestracji w takich przypadkach ${ }^{46}$.

Podobne wnioski dotyczące zakresu ochrony znaku stanowiącego kompozycję kolorystyczną płyną z orzeczenia dotyczącego naruszenia prawa do znaku towarowego, którego właścicielem (powodem) była spółka Red Bull GmbH ${ }^{47}$. Znak ten, stanowiący zestawienie koloru niebieskiego i srebrnego (dalej „znak Red Bull"), został przedstawiony jako układ dwóch barw pokrywających płaszczyzny równej wielkości, przedzielone prostą pionową linią. Takiego układu nie powtarzał w swoim oznaczeniu pozwany. Znak pozwanego (dalej „znak Big Brand”) powtarzał jedynie kolorystykę znaku powoda, gdyż w znaku pozwanego linie obu kolorów biegły ukośnie, a kolorem dominującym był niebieski, podczas gdy kolor srebrny jedynie przecinał ukośnym pasem niebieski prostokąt. Ponadto znak ten zwierał również inne odcienie koloru niebieskiego.

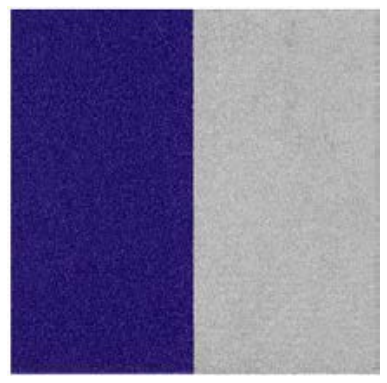

rys. 6 znak krajowy zgłoszony do UPRP dnia 10.03.2006 r., R. 256029, uprawniony: Red Bull

$\mathrm{GmbH}, \mathrm{kl} .32$ - napoje energetyzujące

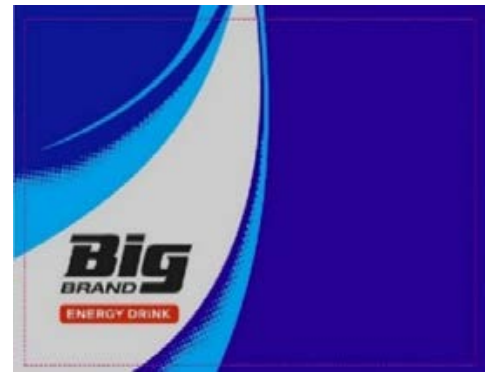

rys. 7 ZTUE zgłoszony do EUIPO dnia 3.07.2013 r., nr 011953155, uprawniony: Big Brands Group sp. z o.o. spółka komandytowa, kl. 32 - napoje energetyzujące

W omawianej sprawie powód zmierzał do zakazania pozwanej spółce oznaczania opakowań napojów energetyzujących opisanym znakiem. Sąd Okręgowy oddalił powództwo w tej sprawie, następnie również apelacja powoda od wyroku sądu pierwszej instancji została oddalona. Organy orzekające obu instancji uznały, że porównywane znaki są niepodobne i nie występuje ryzyko wprowadzenia odbiorców w błąd co do pochodzenia towarów. Następnie sprawa trafiła do Sądu Najwyższego, który skonstatował (podobnie jak w omówionej wyżej sprawie dotyczącej zestawienia koloru zielonego i żółtego), że z samego faktu zaklasyfikowania znaku Red Bull do kategorii znaków barwnych (czyli stano-

${ }^{46}$ Zob. np. kolor zielony per se zgłoszony jako znak towarowy UE dla usług ubezpieczeniowych (ZTUE 000036731); kolor zielono-złoty dla części maszyn (ZTUE 000152314), kolor niebieski dla nawozów mineralnych (ZNUE nr 000156380), kolor pomarańczowy dla m.in. artykułów tytoniowych (ZNUE 004532198) itd.

47 Wyrok SN z dnia 2.02.2017 r. (ICSK 778/15), LEX 2297410. 
wiących kompozycję kolorystyczną nieograniczoną przestrzennie) nie wynika, że ochronie podlega każda jego bezkonturowa postać obejmująca zestawienie dwóch kolorów: srebrnego i niebieskiego. Sąd podkreślił, że określony układ kolorów - obejmujący położenie barw wobec siebie oraz ich proporcje, zgodnie $\mathrm{z}$ wizualizacją przedstawioną w zgłoszeniu (tj. kolor niebieski z lewej strony, kolor srebrny z prawej strony, sposób ich pionowego połączenia w postaci równej linii oraz proporcje obu kolorów równe lub zbliżone do 50:50) - ma znaczenie dla oceny zakresu ochrony tego znaku towarowego. Jednakże Sąd Najwyższy uchylił wyrok Sądu Apelacyjnego i przekazał sprawę do ponownego rozpatrzenia ze względu na nieprawidłowe zastosowanie przez organ niższej instancji przepisów stanowiących podstawę dla ochrony znaków renomowanych, tj. art. 296 ust. 2 pkt 3 p.w.p. Sąd Apelacyjny bowiem badając, czy doszło do naruszenia prawa do znaku renomowanego Red Bull uznał błędnie, że do naruszenia renomowanego znaku towarowego dochodzi wtedy, gdy podobieństwo późniejszego znaku do wcześniejszego renomowanego znaku towarowego jest tego rodzaju, iż może wprowadzić konsumentów w błąd oraz błędnie przyjął że przesłanka naruszenia renomowanego znaku towarowego, tj. podobieństwo między znakiem pozwanego a wcześniejszym renomowanym znakiem towarowym powoda - które może prowadzić do myślowego kojarzenia przez przeciętnego konsumenta obu porównywanych znaków - stanowi fakt wymagający dowodu ${ }^{48}$.

$\mathrm{W}$ przedstawionej sprawie wykluczone więc zostało ryzyko wprowadzenia odbiorców w błąd i w tym zakresie uznano, iż nie doszło do naruszenia prawa do znaku Red Bull. Sam fakt użycia identycznych kolorów w znaku osoby trzeciej nie oznacza automatycznie naruszenia prawa do znaku stanowiącego bezkonturową kompozycję kolorystyczną, jeśli pozostałe elementy znaku potencjalnego naruszyciela pozwalają na wyłączenie ryzyka konfuzji.

Jednakże w analizowanej sprawie nie została jeszcze przesądzona kwestia naruszenia prawa do znaku Red Bull na podstawie przepisów stanowiących podstawę dla ochrony znaków renomowanych. Na rozstrzygnięcie tego aspektu sprawy należy jeszcze poczekać. Można jedynie przypuszczać, że w przypadku kompozycji kolorów, mającej status znaku renomowanego (status ten został przyznany znakowi Red Bull w opisanym wyżej sporze), użycie analogicznych kolorów dla identycznych towarów przez osobę trzecią niezależnie od konfiguracji tych kolorów może wywoływać ryzyko skojarzenia takiego znaku ze znakiem renomowanym, zważywszy na walor szerokiej znajomości i rozpoznawalności znaku cieszącego się mianem znaku renomowanego. Jeśli bowiem założymy, że znaki stanowiące bezkonturową kompozycję kolorystyczna mogą uzyskać status

${ }^{48}$ Zob. wyrok TSWE z 23.10.2003 r. w sprawie C408/01, Adidas-Salomon AG i Adidas Benelux BV v. Fitnessworld Trading Ltd., pkt 29 i 31, tłumaczenie wyroku M. Mazurek, w: Własność przemysłowa. Orzecznictwo Trybunału Sprawiedliwości Wspólnot Europejskich i Sądu Pierwszej Instancji, red. R. Skubisz, Kraków 2004, s. 317. 
renomowanych, konsekwentnie należy przyjąć, że chronione są według zasad właściwych dla znaków renomowanych - czyli wystarczy takie podobieństwo między kolizyjnymi oznaczeniami, które niesie ryzyko skojarzenia niezależne od ryzyka konfuzji, w wyniku czego dochodzi do ryzyka czerpania nienależnych korzyści z renomy lub odróżniającego charakter znaku lub działania na szkodę renomy lub odróżniającego charakter znaku renomowanego (zob. art. 296 us.t 2 pkt 3 p.w.p. $)^{49}$.

\section{Wnioski}

Podsumowując przeprowadzone rozważania należy stwierdzić, że de facto zakres ochrony znaków barwnych (stanowiących kompozycję kolorystyczną bez konturów) jest zbliżony do tego, jaki właściwy jest dla ochrony znaków graficznych przedstawiających kolory zamknięte w figurach geometrycznych o zadanych kształtach. Znak stanowiący kompozycję kolorystyczną nie uzyskuje bowiem ochrony w odniesieniu do wszystkich możliwych zestawień barw objętych rejestracją. Zakres ochrony takiego znaku jest ściśle określony poprzez wskazanie wzajemnych proporcji kolorów i sposobu ich połączenia (np. linia prosta, falowana, rozmyta itp.). Nie oznacza to jednak tożsamego zakresu ochrony obu kategorii znaków towarowych. Jak słusznie zauważył Sąd w sprawie dotyczącej unieważnienia prawa do znaku towarowego Red Bull nawet, jeśli przedstawienie lub opis precyzyjnego układu kolorów przyczyniają się do zbliżenia kompozycji kolorystycznej per se do graficznego znaku towarowego, przedmiot ochrony przyznanej przez te dwie kategorie znaków towarowych pozostaje odrębny ${ }^{50}$. Kompozycja kolorystyczna jako taka (znak barwny) może bowiem być umieszczona, bez konturów, na każdej powierzchni oznaczonych nią towarów, niezależnie od ich formy lub opakowania, co nie odnosi się do graficznych znaków towarowych ${ }^{51}$. Należy więc zgodzić się z poglądem wyrażonym w wyroku w sprawie Red Bull, że przedsiębiorca co do zasady może być

49 Zob. wyrok TSWE z 23.10.2003 r. w sprawie C408/01, Adidas-Salomon AG i Adidas Benelux $B V$ v. Fitnessworld Trading Ltd., pkt 29 i 31, tłumaczenie wyroku M. Mazurek, w: Własność przemysłowa. Orzecznictwo Trybunału Sprawiedliwości Wspólnot Europejskich i Sądu Pierwszej Instancji, red. R. Skubisz, Kraków 2004, s. 317 oraz podobnie wyrok TSUE z 6.07.2012 r., w sprawie ROYAL SHAKESPEARE, T60/10, pkt 19; wyrok TSUE z 5.07.2016 r., w sprawie T518/13, Future Enterprises Pte Ltd vs. OHIM (MCDONALDS), pkt 37; wyrok TSWE z 10.04.2008 r. w sprawie C102/07, Adidas $i$ Adidas Benelux v. Marca Mode CV i inni, s. I2439, pkt 41; wyrok TSWE z 18.06.2009 r., w sprawie C487/07, L'Oréal SA, Lancôme parfums et beauté \& Cie SNC, Laboratoire Garnier \& Cie v. Bellure NV, Malaika Investments Ltd, Starion International Ltd., pkt 36.

${ }_{50}$ Zob. wyrok w sprawie Red Bull GmbH, pkt 74 .

${ }^{51}$ Zob. wyrok w sprawie Red Bull GmbH, pkt 75 oraz podobnie wyrok Sądu z 28.01.2015 r. w sprawie T655/13, Enercon v. OHIM, pkt 16. 
zainteresowany uzyskaniem ochrony znaku stanowiącego kompozycję kolorystyczną per se ze względu na szerszą ochronę, jaką zapewnia prawo podmiotowe do tego rodzaju znaków w stosunku do ochrony właściwej dla graficznego znaku towarowego ${ }^{52}$. Należy jednak pamiętać, że nie tylko w przypadku znaku graficznego, ale również barwnego ochrona ograniczona jest do przedstawienia graficznego znaku zawartego w zgłoszeniu zgodnie z regułą „otrzymuje się to, co widać" (ang. „what you see is what you get") ${ }^{53}$.

$\mathrm{W}$ istotnym stopniu odróżnia to idee stojącą u podstaw ochrony pojedynczego koloru per se. W przypadku bowiem udzielania ochrony na pojedynczy kolor jako taki, uprawniony uzyskuje monopol na używanie danego koloru w odniesieniu do towarów, dla których dokonane zostało zgłoszenie. W związku $\mathrm{z}$ tak dalekimi konsekwencjami dokonania rejestracji koloru jako takiego na rzecz jednego przedsiębiorcy, Trybunał Sprawiedliwości wyraźnie zwracał uwagę na to, że „rodzaj towarów dla jakich dokonane zostało zgłoszenie wniosku o rejestrację znaku stanowiącego kolor per se ma znaczenie zarówno dla określenia charakteru odróżniającego koloru zgłoszonego w charakterze znaku towarowego, jaki i dla określenia, czy jego rejestracja nie byłaby sprzeczna $\mathrm{z}$ interesem ogólnym, przejawiającym się $\mathrm{w}$ tym, by nie ograniczać $\mathrm{w}$ sposób nieuzasadniony dostępności kolorów dla innych przedsiębiorców, oferujących towary lub usługi tego samego rodzaju co towary lub usługi, dla których żąda się rejestracji znaku towarowego" ${ }^{54}$. Tak poważne „ograniczenia kolorystyczne" w odniesieniu do danego rynku nie występują w przypadku rejestracji znaku stanowiącego kompozycję kolorystyczną ze względu właśnie na wspomniane ograniczenie jego zakresu ochrony.

Należy jednak zaznaczyć, że wspomniane podejście do zakresu ochrony koloru per se jest przedmiotem krytyki w doktrynie ${ }^{55}$. Ponadto już rzecznik generalny TS Léger w opinii w sprawie Libertel zauważył, że kolor per se nie powinien być w ogóle rejestrowany jako znak towarowy, m.in. ze względu na to, że nie stanowi on bytu niezależnego, będąc zawsze atrybutem czegośs ${ }^{56}$. Co więcej w przypadku znaku będącego kolorem jako takim nie wiadomo, w jaki sposób uprawniony będzie używał znaku (na całości, czy tylko części towaru i ewentualnie w jakiej konfiguracji), co oznacza de facto, że uprawniony otrzymuje

52 Wyrok w sprawie Red Bull GmbH, pkt 75.

${ }_{53}$ Wyrok w sprawie Red Bull GmbH, pkt 71.

${ }^{54}$ Wyrok w sprawie Libertel, pkt 71.

${ }_{55}$ Zob. M. Mazurek, Rejestracja pojedynczego koloru ..., s. 240, Autor jednak uważa, że: „Mniej wątpliwa jest rejestracja prostego oznaczenia składającego się z koloru określonej powierzchni przedmiotu."; A. Ziarno, Zdolność rejestrowa koloru per se jako wspólnotowego znaku towarowego, ZNUJ 2011/126, s. 153.

${ }^{56}$ Opinia rzecznika generalnego TS Léger do wyroku w sprawie Libertel, pkt 67. 
prawo wyłączne do różnych znaków towarowych ${ }^{57}$. Takie podejście nie pozwala na realizację podstawowej funkcji znaku towarowego, jaką jest wskazywanie na pochodzenie towaru $\mathrm{z}$ określonego przedsiębiorstwa ${ }^{58}$.

\section{Piśmiennictwo:}

Kępiński M., Projekt nowej dyrektywy dotyczącej znaków towarowych i jej możliwe konsekwencje dla ustawodawcy polskiego, Zeszyty Naukowe Uniwersytetu Jagiellońskiego PPWI 2014/126

Kicia M. (w:) Kolor per se jako znak towarowy w świetle orzecznictwa europejskiego, Rzecznik Patentowy, 2004/1-2

M. Trzebiatowski, (w:) System Prawa Prywatnego. Prawo własności przemysłowej, R. Skubisz (red.), T. 14B, Warszawa 2012

Mazurek M., Rejestracja pojedynczego koloru jako znaku towarowego, Zeszyty Naukowe Uniwersytetu Jagiellońskiego PPWI 2004/86

Mazurek M., w: Własność przemysłowa. Orzecznictwo Trybunału Sprawiedliwości Wspólnot Europejskich i Sądu Pierwszej Instancji, red. R. Skubisz, Kraków 2004

Promińska U., Ustawa o znakach towarowych. Komentarz, Warszawa 1998

Promińska U., (w:) E. Nowińska, U. Promińska, M. du Vall, Prawo własności przemysłowej, Warszawa 2008

Sitko J., Trade marks with a reputation and famous marks: differences in approach between the European Union, Poland and the United States in relation to the principle of speciality, Queen Mary Journal of Intellectual Property (Queen Mary University of London) 2017/7

Skubisz R., Glosa do wyroku NSA z dnia 23 listopada 2004 r., GSK 864/04, Orzecznictwo Sądów Polskich 2005/9/108

Skubisz R., Prawo z rejestracji znaku towarowego i jego ochrona. Studium z zakresu prawa polskiego na tle prawno-porównawczym, Lublin 1988

Skubisz R., Prawo znaków towarowych. Komentarz, Warszawa 1997

Skubisz R., Zdolność odróżniająca znaku towarowego w orzecznictwie Trybunału Sprawiedliwości Wspólnot Europejskich, (w:) „Biuletyn Politechniki Świętokrzyskiej”, red. A. Adamczak, Kielce 2005, z. 29

Szczepanowska-Kozłowska K., (w:) System Prawa Prywatnego. Prawo własności przemysłowej, R. Skubisz (red.), T. 14B, Warszawa 2012

Szwaja J., Wojcieszko-Głuszko E., Mika I.B., Kumulacja praw własności przemysłowej w prawie polskim (na przykładzie wzorów przemysłowych i znaków towarowych), Kwartalnik Prawa Prywatnego 2001/2

Tylec G., Glosa do wyroku SN z dnia 3 czerwca 2009 r. (IV CSK 61/09), Orzecznictwo Sądów Polskich 2010/12/124

Ziarno A., Zdolność rejestrowa koloru per se jako wspólnotowego znaku towarowego, Zeszyty Naukowe Uniwersytetu Jagiellońskiego PPWI 2011/126

\section{Streszczenie}

Kompozycja kolorystyczna to, zgodnie z przepisami ustawy prawo własności przemysłowej, jedna z postaci w jakiej może występować znak towarowy. Pojęcia tego używa się dla określenia znaków

${ }^{57}$ Ibidem, pkt 68-70.

${ }^{58}$ Zob. M. Mazurek, Rejestracja pojedynczego koloru ..., s. 241. 
towarowych stanowiących zestawienie dwóch lub więcej kolorów per se. Jest to specyficzna kategoria oznaczeń, względem których - w bogatym orzecznictwie prejudycjalnym Trybunały Sprawiedliwości wypracowane zostały szczegółowe zasady ich prezentacji w rejestrze. Z utrwalonej już linii orzeczniczej (zarówno sądów polskich, jak i unijnych) wynika, że oprócz graficznej prezentacji kompozycji kolorystycznej, bardzo istotnym elementem zgłoszenia takiego znaku jest jego opis, w którym oprócz podania słownej nazwy koloru i jego numeru według określonej międzynarodowej klasyfikacji kolorów, konieczne jest również określenie stałego sposobu połączenia barw tworzących znak. Wskazane wymogi dotyczące prezentacji znaku w rejestrze determinują jego zakres ochrony. Pomimo wiec tego, że przedmiotem zgłoszenia w przypadku kompozycji kolorystycznej jest bezkonturowy układ dwóch lub więcej barw, ochrona de facto zbliżona jest do tej, jaka właściwa jest dla ochrony znaków graficznych przedstawiających kolory zamknięte w figurach geometrycznych o zadanych kształtach. Zakres ochrony takiego znaku jest bowiem ściśle określony poprzez wskazanie wzajemnych proporcji kolorów i sposobu ich połączenia (np. linia prosta, falowana, rozmyta itp.). Znak stanowiący kompozycję kolorystyczną nie uzyskuje więc ochrony w odniesieniu do wszystkich możliwych zestawień barw składających się na dany znak.

Rozważania zawarte w prezentowanym artykule dotyczą również zmiany wprowadzanej przez dyrektywę 2015/2436 w zakresie graficznej przedstawialności znaku i jej wpływu na sposób prezentacji znaków stanowiących kompozycję kolorystyczną. Zagadnienie to omówione zostało w kontekście szczegółowych wytycznych płynących z rozporządzenia wykonawczego 2017/1431 dotyczącego znaku towarowego Unii Europejskiej.

Słowa kluczowe: znak towarowy, kompozycja kolorystyczna, kolor per se, graficzna przedstawialność znaku, zdolność odróżniająca.

\section{Terms of Registration and Scope of Protection of Combinations of Colours as Trade Marks}

\section{Summary:}

Pursuant to the provisions of the Act of 30 June 2000 on Industrial Property Law, combinations of colours may be considered as trademarks. This notion applies to trade marks which bear an arrangement of two or more colours per se. It is a specific category of denominations with respect to which detailed principles for the presentation thereof in a relevant register has been developed in the preliminary rulings of the European Court of Justice. It follows from the well-established jurisprudence of Polish and EU courts alike that in addition to the graphic presentation of a combination of colours, the description of the relevant trade mark in an application for trade mark protection plays a major role. Such a description should include, besides specifying the colour and its number in the international classification of colours, information on the fixed arrangement of colours that constitute the trade mark. Such requirements concerning the presentation of the trade mark in the register determine the scope of its protection. Despite the fact that the object of the application concerning a combination of colours is a contour-free arrangement of two or more colours, the actual protection is similar to that which is proper for the protection of graphic signs composed of colours enclosed in defined geometrical figures. The scope of protection of such a trade mark is strictly determined by indicating mutual relations between/among colours and the manner in which they are linked (e.g., straight line, undulating line, colour blur, etc.). Thus, a trade mark with a combination of colours is not subject to protection with respect to all possible arrangements of colours that make up a given trade mark.

The considerations presented in this article also refer to the changes introduced in Directive (EU) $2015 / 2436$ on the graphic representation of a trade mark and its effects on the presentation 
of trade marks which constitute a combination of colours. This issue is presented in the context of detailed guidelines that stem from the Commission Implementing Regulation (EU) 2017/1431 concerning the European Union trade mark.

Keywords: trade mark, combination of colours, colour per se, graphic representation, distinctive character. 